\title{
Stepping Stone, Stopping Point, or Slippery Slope? Negotiating the Next Iran Deal
}

\section{Citation}

Sebenius, James K. "Stepping Stone, Stopping Point, or Slippery Slope? Negotiating the Next Iran Deal." Harvard Business School Working Paper, No. 14-061, January 2014. (Revised March 2014.)

\section{Permanent link}

http://nrs.harvard.edu/urn-3:HUL.InstRepos:12111353

\section{Terms of Use}

This article was downloaded from Harvard University's DASH repository, and is made available under the terms and conditions applicable to Open Access Policy Articles, as set forth at http:// nrs.harvard.edu/urn-3:HUL.InstRepos:dash.current.terms-of-use\#OAP

\section{Share Your Story}

The Harvard community has made this article openly available.

Please share how this access benefits you. Submit a story.

Accessibility 
H A R V A R D

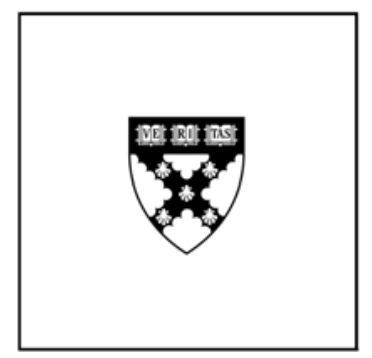

\title{
Stepping Stone, Stopping Point, or Slippery Slope? Negotiating the Next Iran Deal
}

\author{
James K. Sebenius
}

\section{Working Paper}

14-061

March 24, 2014 


\section{Stepping Stone, Stopping Point, or Slippery Slope? \\ Negotiating the Next Iran Deal (v. 3.0, 3/24/14)}

James K. Sebenius ${ }^{1}$

Abstract: The November 2013 "interim" nuclear deal between Iran and the "P5+1"-the United States, Russia, China, Britain, France, and Germany-raises challenging questions. Will the initial deal function as a stepping stone toward a more comprehensive deal? Or will it drift into becoming a stopping point that leaves Iran dangerously close to nuclear weapons capability with the sanctions regime in decline? Or will it devolve to a slippery slope that would end up requiring a painful choice for key players between either acquiescing in a nuclear-capable Iran or attacking Iran's nuclear facilities? With the Iran and the P5+1 each splintered into contending factions, a successful stepping stone strategy requires converting enough "persuadable skeptics" on each side to forge a "winning coalition" on behalf of the a more comprehensive nuclear deal. This supportive group must be strong enough to overcome the potent "blocking coalition" that will oppose virtually any larger, next-stage agreement. The best chance for the interim accord to become a stepping stone to a more valuable deal calls for a two-prong negotiating strategy with both value-enhancing and cost-imposing elements. The first prong of this strategy should strive to craft the most valuable possible next deal that credibly offers Iran a range of benefits, not limited to sanctions relief, that are greater and much more salient than those available from the interim agreement. The second prong should significantly worsen the consequences of failing to reach the next nuclear deal by a strong public U.S. Presidential commitment to sign a bill, prenegotiated with the Congress and P5+1 allies, imposing enhanced sanctions if negotiations toward an acceptable, but relatively narrow, agreement denying Iran an "exercisable nuclear option" do not succeed by the reasonable but firm deadline no later than twelve months from the start of the interim talks.

Keywords: negotiations, Iran, nuclear, conflict resolution, winning coalition, blocking coalition

The "interim” nuclear deal with Iran has sparked bitter controversy. This agreement temporarily freezes or rolls back key elements of Iran's nuclear program in return for six months of modest sanctions relief. ${ }^{2}$ Yet, more than two months into negotiations to, predictions diverge sharply about where future negotiations will lead.

Will the initial deal function as a stepping stone toward a more comprehensive deal in which fears of a nuclear-capable Iran justifiably recede, sanctions lift, and just conceivably, mutual enmity slowly subsides?

Or will this first deal drift into becoming a stopping point that leaves Iran dangerously close to nuclear weapons capability with the sanctions regime in decline?

Or will the interim deal devolve, perhaps from a temporary stopping point, to a slippery slope that would end up requiring a painful choice between two costly, risky outcomes: either acquiescing in a nuclear-capable Iran or attacking Iran's nuclear facilities?

Reaching a worthwhile next deal will be extremely tough. Deep interests and perceptions clash. Years of enmity and powerful blockers on all sides raise high barriers. Indeed, it is uncertain whether a set of deal terms even exists that would meet each side's core interests well enough to attract sufficient support for acceptance. If such terms do not exist, even the most brilliant negotiating strategy won't succeed. ${ }^{3}$ But if an underlying zone of possible agreement 
does exist, failing to uncover it as the result of a deficient process or insistence on unattainable terms would be tragic.

With the Iran and the "P5+1"- the United States, Russia, China, Britain, France, and Germany - each splintered into contending factions, a successful stepping stone strategy requires converting enough "persuadable skeptics" on each side to forge a "winning coalition" on behalf of the next nuclear deal. This supportive group must be strong enough to overcome the potent "blocking coalition” that will oppose virtually any larger, next-stage agreement.

Analysts differ on two main questions over which negotiating approach offers the best shot for the interim accord to become a stepping stone to a next deal. First, should tactics emphasize inducement and cooperation or pressure, especially through intensified sanctions? ${ }^{4}$ Second, in return for sanctions relief, should a fairly narrow deal with tight limits on Iran's nuclear activities and strict verification measures be acceptable? Or should a broader deal be required that commits Iran to accept nuclear limits but also to end its support for terror, Hezbollah, Hamas, and Assad; to ensure better human rights practices, etc. ${ }^{5}$

Bottom line: the best shot for the interim accord to become a stepping stone to a more valuable deal calls for a two-prong negotiating strategy with both value-enhancing and costimposing elements. The first prong of this strategy should strive to craft the most valuable possible comprehensive nuclear deal that credibly offers Iran a range of benefits, not limited to sanctions relief, that are greater and more salient than those available from the interim agreement. The second prong should significantly worsen the consequences of failing to reach the next nuclear deal by a credible mechanism, described below, to impose enhanced sanctions if negotiations toward an acceptable, but relatively narrow, agreement do not succeed by a reasonable but firm deadline.

How strenuously the parties negotiate and the risks they will take to reach the next deal depend on its perceived value. Analysts often fail to realize that this value depends not only on deal terms themselves but, critically, on the perceived no-deal alternative; that is, how the parties answer the question "the proposed deal-as compared to what?" The appeal of the next deal will be far greater if the no-deal outcome entails certainty of an enhanced sanctions regime rather than if no-deal means falling back on the interim accord as an easier stopping point-which could easily become a slippery slope.

Hence the two-prong strategy's emphasis on crafting the most valuable possible deal while worsening the no-deal outcome. The challenges of effectively deploying both carrot and stick are real but common in difficult negotiations - and can most likely be surmounted by skillful diplomacy in the coming nuclear talks.

The Next Deal: A Contest Among Skeptics. Assembling a winning coalition in support of a larger deal requires disaggregating the "sides"-broadly, Iran versus the P5+1 and its putative allies on this issue such as Israel, Saudi Arabia, and other Gulf states. Complex internal alignments on each "side" are very much in play as a function of the character of the upcoming negotiation process as well as the terms of a more comprehensive deal. Oversimplifying, the nuclear talks have set up a contest involving three groups on each side: a cautious and 
provisional “deal-favoring faction,” a larger group of “persuadable skeptics,” and a set of unconditional opponents of virtually any feasible next deal.

First, each side now has a cautious and provisional "deal-favoring” faction. For the Americans, this is the Obama administration plus key P5+1 members; for the Iranians, Rouhani and his current political supporters following his somewhat surprise election. These factions largely provided the backing for the interim agreement but cannot, by themselves, provide sufficient support for a next deal. If the terms of the next agreement are right-and if this Iranian faction is sincere- these groups will work both with each other and with their respective sides in favor of the deal, mainly seeking to transform enough skeptics into supporters.

Second, a much larger group of suspicious but "persuadable skeptics" on each side is inclined toward opposition, but ultimately is at least open to the possibility of a next deal that offers real benefits relative to impasse. For this second group, as for the deal-favoring (first) faction, the interim agreement mainly provides a direct opportunity to test the other side's real intentions after more than three decades with essentially no direct official communication (between the U.S. and Iran), mutual hostility, and polarization. And test they will, especially whether each side observes the letter and spirit of the interim agreement. Apart from the actual deal terms, these factions will relentlessly scrutinize the upcoming process for signs that the other side is serious ... or not.

Think of these potentially persuadable deal skeptics on both sides as the swing parties in a fierce contest between deal-favorers and a third group of unconditional opponents (described below). A successful deal requires the support of enough Iranian skeptics to tip the internal political balance enough to make it more politically appealing, for Khamenei to agree if he ultimately so chooses - hardly a certainty. Similarly, if enough American, Israeli, and Saudi skeptics become supportive of or at least neutral toward the next deal, the Obama administration will find it much easier to successfully press for its acceptance.

Iranian skeptics will watch for the other side's genuine willingness to lift sanctions and provide benefits as well as to dial down hostile activities widely attributed to American and Israeli sources such as cyber-attacks, mysterious explosions, assassinations of nuclear scientists, and the like. Potentially supportive but skeptical P5+1 members as well as important groups of Israelis, Saudis, Gulf countries, and domestic U.S. players will shift from "mere” skeptics into outright opponents at serious signs of Iranian duplicity, diplomatic trench warfare, hostile domestic pronouncements, or cheating on the interim deal's requirements (especially after Iran's failure to comply with its 2003 nuclear deal with France, Germany, and the UK_-and against the backdrop of frequent North Korean noncompliance with similar deals).

The third faction, “deal blockers," consists of unconditional opponents who sought to stop the interim deal and will fight virtually any larger accord in part by recruiting allies from the second faction of deal skeptics. If Ayatollah Khamenei ends up firmly into this group, he would serve as a one-man blocking coalition, and no deal would be possible. It is difficult to disentangle blockers' interests in a nuclear deal per se from their broader political interests. In Iran, much of the Revolutionary Guard and many conservative clerics—already fighting a rearguard action against the interim deal ${ }^{6}$ — want to put a stop to Rouhani and his allies however the nuclear talks play out. In Israel and the United States as well as among Gulf states, important 
conservative groups will denounce "fatal flaws" both on the merits of almost any next deal and as a corollary to their ironclad belief that Obama is disastrously naïve and dangerous across his entire Middle Eastern policy.

The First Prong of a Stepping Stone Strategy: Value-Enhancing Moves. A necessary condition for success is that the main substantive terms of the next deal meet the core interests of each faction of a potential winning coalition: tight limits on Iran's nuclear activities, strict verification measures, substantial sanctions relief. Unless an agreement does this and offers confidence that each side will comply, assembling a winning coalition from among deal-favorers and skeptics above in favor of a next agreement is virtually out of the question.

Beyond these necessary conditions, several "first prong" actions could enhance the perceived value of the next deal relative to the costs of no deal. Such actions could make these potential benefits more salient, cut against the hardline Iranian narrative, and increase the odds of enough persuadable skeptics joining a supportive coalition strong enough to overcome the blockers

For 34 years with no diplomatic relations or official communication between the United States and Iran, hardliners in Tehran have portrayed the United States and its allies as implacable, interested only in sanctions and threats. (And these hostile perceptions, of course, have been mutual, caricatured as the "Great Satan vs. the Mad Mullahs."7) As a result, skeptics and blockers_-both genuinely and cynically_can easily sow doubt that the U.S.-led coalition would ever deliver meaningful benefits as part of a nuclear deal.

To counter this hostile narrative, the United States should orchestrate a far more persuasive campaign that targets potentially persuadable Iranian skeptics, helping to build the largest possible constituency for a deal.

Given the potent negative effects of sanctions, lifting them in return for credible Iranian nuclear limits obviously ranks highest among value-enhancing actions. ${ }^{8}$ During the first six months while the fuller deal is being negotiated, quite modest sanctions relief, doled out in carefully calibrated increments, is provided by the interim accord; the Administration says the figure is $\$ 7$ billion worth of direct benefit to Iran, while some analysts say the direct and indirect effects are closer to a $\$ 24$ billion boost to the Iranian economy. This action permits persuadable Iranian skeptics and other potential deal supporters to directly experience meaningful economic benefits — as has happened even in anticipation of the interim deal ${ }^{9}$ — with far more sanctions relief credibly available on a progressive basis under the right next deal.

But U.S. negotiators should do more to dramatize the much larger potential benefits that would accrue to Iran with—but only with—the signing and implementation of a fuller deal.

Oil sanctions relief would increase Iran's oil output and global sales (placing downward pressure on world oil prices). To make oil sanctions relief more publicly salient, negotiators should encourage international oil companies and other businesses to send well-publicized missions to Iran to demonstrate advanced technology and investment willingness. 
High-profile measures could be undertaken to set up — conditional on a comprehensive deal - trade initiatives as well as technical, financial, and other assistance to agriculture, civil aviation (including spare parts), transport, telecommunication, and other non-oil sectors. U.S. and European scientific teams could likewise be dispatched to explore potential areas of cooperation with Iranian scientists in non-nuclear fields.

In the realm of regional policy, it may be useful to raise the possibility reactivating cooperation in areas of mutual benefit where both sides have showed genuine interest in the past. Examples include joint counter-narcotics activities, Afghan security, and anti-Taliban moves. Such actions could serve as the basis for cautiously exploring the potential for a wider and more constructive Iranian regional role. The idea would not be to expand the agenda of the interim talks, but to make more salient the possibility of acting on mutual interests. Beyond these examples, there are many more potentially value-enhancing moves. ${ }^{10}$

In line with the idea of a campaign to dramatize the benefits of a comprehensive nuclear deal, several European countries, especially France and Germany, have sent business and trade missions to Teheran in anticipation of the end of sanctions. ${ }^{11}$ For the most part, the Obama administration has strenuously opposed such commercial initiatives concerned that they would weaken the sanctions regime. (In a notable recent exception, which should be much more widely publicized, the administration authorized U.S. academic exchanges with Iranian universities. ${ }^{12}$ )

While administration opposition is understandable, a coordinated campaign for Western companies and scientists to more visibly tout their wares in Iran could potently counter the hardline Tehran narrative. It could persuasively demonstrate that, given a deal, no Western agenda exists to frustrate Iran's scientific progress or economic development. Targeting skeptics in this way would help mobilize potential supporters and isolate Iranian hardliners opposed to a deal.

Such forthcoming actions would also help persuade allies that the United States is serious about diplomacy, something that will be important if negotiations fail and allied support is needed for tougher measures as set forth in "prong two" of the recommended approach.

With proper planning and expectations-setting with $\mathrm{P} 5+1$ allies, such a campaign targeting skeptics need not undermine the sanctions regime. Without a final nuclear deal, none of these tantalizing benefits for Iran would be realized. In Obama's words, governments could still come down "like a ton of bricks" on sanctions violators. ${ }^{13}$

It is true that prior Iranian negotiators have shown scant interest in incentives beyond sanctions relief. ${ }^{14}$ It may be that such incentives were viewed as mere hypothetical possibilities rather than real options. Yet, even if credible, one party's genuine disinterest in incentives at an earlier stage of negotiations need not mean its later disinterest in the very same incentives, especially if that party's no-deal options have been badly degraded in the interim as has been the case for Iran, especially with tightening oil, financial, and central bank sanctions since 2010.

By analogy, the potential acquirer of a business firm may initially offer substantial inducements to its founder/CEO — who may indignantly reject such payments and other offers. One might reasonably conclude that the CEO has "no interest in such incentives." Yet, suppose 
the acquirer goes into the stock market and buys a large block of the target's shares, credibly threatening the founder with loss of control. Although contemptuously rejected earlier, renewed (identical) offers of substantial cash and a future role may now be keenly interesting to the founder/CEO in return for a "friendly" deal . . . given his dramatically worse no-deal options. So too, with a sanctions-damaged Iranian regime that earlier scoffed at incentives. (Plus, some of the key parties have changed with Rouhani's election. New players may value the identical incentives differently from earlier Iranian negotiators. And, if the interim deal is implemented, the credibility of future incentives would be enhanced.)

Caution: offering beneficial deal terms that may help the hardline regime ensure its survival-for example by fostering oil production or offering security guarantees — can be morally problematic and politically costly as can giving the perception of an Iranian "victory" or appearing to reward bad behavior. Thus, along with their appeal to persuadable skeptics in Iran, candidate incentives should be assessed in terms of how costly-in political, economic, security, and/or moral terms - such measures would be to persuadable skeptics among the P5+1 block. The trick is to find and emphasize those benefits of highest value (for recruiting Iranian skeptics) at lowest cost (to pro-next deal efforts among the U.S. and its allies).

\section{Prong Two: Conditional Sanctions to Prevent Stopping Point and Slippery Slope}

Outcomes. In addition to wooing skeptics, a winning strategy must thwart determined Iranian blockers who seek a nuclear capability and will try to prevent meaningful concessions. After six months of talks, there could easily be positive atmospherics but little real progress. P5+1 and Iranian diplomats could seductively request "just a bit more time since we're locked in intense negotiations that promise imminent breakthroughs.” Relative to the prospect of escalating hostilities, many factions on each side will view the interim deal as preferable-with key elements of the Iranian nuclear program (reversibly) paused or rolled back and some sanctions relief.

This possibility has led to predictions by sophisticated analysts about a likely six-month extension of the talks, an option built into the interim deal. ${ }^{15}$ This "drift" could easily become an indefinite pattern, turning some version of the interim deal into a de facto stopping point.

Meanwhile, as the process continues, Western companies continue to lobby their governments to permit Iranian contracts, the will of allies to support sanctions erodes, diplomatic focus shifts, and Iran's nuclear program quietly advances.

Already, evidence has mounted of sanctions-evading Turkish "gold for gas" efforts as well as a potentially $\$ 1.5$ billion per month "oil for goods" deal between Iran and Russia. ${ }^{16}$ As Ali Akbar Salehi, head of Iran's nuclear agency, said on state television about the effects of the interim deal, "The iceberg of sanctions is melting while our centrifuges are also still working." ${ }^{17}$

Former Secretary of State James Baker wisely observed of his allied coalition-building negotiations to unify Germany within NATO and to eject Saddam Hussein from Kuwait: putting such coalitions together was "difficult” but maintaining them was "plenty difficult.” Many people, Baker presciently said, "repeatedly underestimated the difficulty of holding the coalition together for an extended period. Eventually, a key partner was likely to bolt, in which case the coalition would likely disintegrate.” The interim deal with Iran helped hold the P5+1 together by demonstrating genuine willingness to reach agreement; focusing on value-creating moves during 
the negotiations will help further. However, more is needed to serve as a bulwark against the inevitable pressures for the Iran sanctions coalition to fragment if the interim deal increasingly looks like a stopping point.

If the first prong of the two-prong strategy is designed to make the value of a deal high enough to tempt skeptics into a winning coalition, the second prong would make the failure to reach an acceptable comprehensive deal far more costly. For this, the negotiations need a credible deadline backed by meaningful consequences. Solemn verbal pronouncements by multiple American administrations and their allies about firm deadlines-easily seen as "cheap talk"-won’t do it. Such declarations can lack credibility given years of steadily receding "red lines"-more and more advanced stages in the Iranian nuclear program that the United States and its allies first declared to be unacceptable ... and then, when Iran crossed those red lines, effectively accepted as a fait accompli. ${ }^{18}$

To boost its credibility - and to help with its own domestic and allied skeptics -- the administration should pre-negotiate a harsh new “contingency” sanctions package ${ }^{19}$ with Congress and work hard to ensure buy-in from U.S. allies. But instead of signing the sanctions bill immediately, Obama should —at an appropriate pause point in the ongoing talks_-publicly and forcefully commit to signing it if there is no acceptable agreement (described below) no later than the end of one, six-month extension of the interim deal. The right kind of contingent sanctions bill passed with deep bipartisan support, coupled with a strong public presidential commitment to sign it by a specific date, will enhance U.S. credibility, highlight the very real downsides for Iran of no deal, and make it harder for blockers to gain traction in Tehran.

The Obama administration wisely and successfully opposed a recent sanctions bill sponsored by Sen. Robert Menendez (D-N.J.) and Sen. Mark Kirk (R-I.L.). Their "Nuclear Weapon Free Iran Act of 2013” usefully included the concept of “contingent sanctions,” but went far beyond essential nuclear objectives, entailing a high risk of overly stringent, deal-killing requirements. ${ }^{20}$ The Obama administration and a number of experienced U.S. diplomats argued that it would end negotiations by violating at least the spirit of the interim deal (which rules out new sanctions during negotiations ${ }^{21}$ ), souring the atmosphere, and playing into the hardline narrative. ${ }^{22}$ Opponents of the bill were right to oppose its excessive requirements but wrong to miss the potential of more credible contingent sanctions.

Many members of Congress, both Republican and Democratic, as well as influential Israeli, Saudi, French, and other allies do not see contingent sanctions as mere bargaining tactics or posturing, but as vital elements of a bargaining strategy, a "diplomatic insurance policy" in the words of Menendez. ${ }^{23}$ The Obama administration and its deal-favoring allies, while eager to avoid enhanced sanctions as an outcome of the interim negotiations, should capitalize on the potential forcing value of an appropriate form of contingent measures.

Thoughtful observers would likely contend that even contingent sanctions of the form proposed here would run real risks with the interim negotiations. ${ }^{24}$ Iranian negotiators will surely claim bad faith in any "threatening" moves toward contingent sanctions and may well walk out, at least temporarily. Yet if the benefits of a deal are high, the costs of no-deal are substantial, and the diplomatic process is respectful and focused on the positive, it is doubtful that such action will be fatal to negotiation. 
After all, if the atmosphere of the interim negotiations would be at great risk due to explicit threats of harsher sanctions should the talks fail, both by the President and Secretary of State would have already blown it by what they've publicly said. For example, as President Obama stated in December 2013, if Iran can't give “assurances that [they are] not going to weaponize, if they're not willing to address some of their capabilities that we know could end up resulting in them having breakout capacity, it's not going to be hard for us to turn the dials back, strengthen sanctions even further. I'll work with members of Congress to put even more pressure on Iran. . . . the Iranians will know that if negotiations fail even new and harsher sanctions will be put into place." ${ }^{25}$ Secretary Kerry similarly declared that "as we negotiate, we will continue to be perfectly clear that, for Iran, the price of noncompliance, of failing to satisfy international concerns about the nuclear program, will be that we immediately ratchet up new sanctions, along with whatever further steps are needed to prevent Iran from acquiring a nuclear weapon, including . . . a military option, if that were necessary."26

As these statements make clear, the real negotiating problem is not atmospherejeopardizing threats. A deeper problem is their credibility, especially the lack of any forcing mechanism such as a specific deadline. The recommended contingent sanctions bill passed with deep bipartisan support, coupled with a strong public presidential commitment to sign it by a specific date would go a long way toward remedying this problem.

In their role as the "good cops" fighting the inevitability of contingent sanctions by crafting a good deal, the $\mathrm{P} 5+1$ negotiators should relentlessly devise and stress the benefits of a "yes," though in the dark shadow of enhanced sanctions in the event of failure. It is hardly beyond the finesse of skilled diplomats to persuasively highlight and offer the positives while soberly warning - not explicitly threatening the other side-of the negatives of failure to conclude at least a narrow nuclear deal. However, for this second prong of the strategy to prevent stopping point or slippery slope outcomes, while still promoting the next agreement, four conditions should be met:

First, where at all possible, the imposition of such contingent sanctions should be legally binding on the United States, which should negotiate as much advance buy-in of the P5+1 as can be achieved. Negotiators hate to have their hands tied, but this is a case where doing so should be a forcing device against those who would be content with, or even favor, multiple extensions of the interim deal if a comprehensive deal proves elusive. Without a deadline and worse alternatives to failure, the odds rise steeply of the interim deal becoming a stopping point or worse.

Second, the triggering deadline should be realistic, allowing time to negotiate the genuine technical complexities involved and to build internal support on all sides for the larger deal—but not for time-consuming posturing. The outer time limit should be the one-year expiration of the contemplated six-month extension.

Third, the requirements that the next deal must meet to avoid triggering enhanced sanctions must be appropriately crafted. A too-specific list of necessary provisions may block creative diplomacy that could otherwise meet core P5+1 interests. Instead of detailed specifics, the next deal should limit Iran’s potentially military nuclear capabilities sufficiently to satisfy a 
clear "necessary criterion" that it verifiably prevents Iran from advancing toward a military nuclear option without being detected well in advance. Graham Allison characterizes a useful version of this criterion as an "exercisable nuclear option." 27 The trigger should not go beyond this core interest in the ways that the Menendez-Kirk bill did. It should not require major changes in Iran's non-nuclear behavior as some analysts urge.$^{28}$ Instead, the administration and its allies should work with bill sponsors to set the enhanced sanctions trigger no higher than necessary to meet the above necessary criterion.

Fourth, to avoid triggering such sanctions, a mechanism could usefully be devised to "certify" the next deal as meeting the necessary criterion. At a minimum, the President would have to make such a certification. Here are some other mechanism possibilities in addition to a required Presidential finding: the International Atomic Energy Agency might be required to declare that all of its outstanding questions about Iran's nuclear programs had been satisfactorily answered and that Iran's current program was verifiably peaceful. Further, an expert bipartisan panel of former national security officials might be required to concur. Upon review of the next deal, a suitable majority vote, say two-thirds of the Senate, might be sufficient to overturn the Presidential determination and thereby trigger the enhanced sanctions.

Designed properly, such certifications -- coupled with the administration's likely unexpected decision to work proactively with Congress on contingent sanctions -- would also help reassure U.S. and allied skeptics, who worry that the administration is too soft. (Indeed, after the administration and its allies defeated the Menendez-Kirk bill, 83 Senators and 394 House members wrote the administration urging tough conditions for an acceptable deal. ${ }^{29}$ )

Such carefully structured contingent enhanced sanctions should be compatible with cooperative negotiations toward a comprehensive deal. Much of the opposition to the Menendez-Kirk bill was aimed not at the concept of contingent sanctions but at its specific “deal-killing” requirements which were too detailed, too stringent, too expansive, and likely unachievable. To function properly, the trigger criterion and mechanism would have to be appropriately modified (as suggested above). But when both the President and Secretary of State, have in effect threatened Iran with contingent enhanced sanctions if negotiations do not produce a satisfactory result, the risk of a more specific threat, if suitably focused on narrow nuclear objectives, does not appear significant relative to the negotiating benefits.

It is true that when economically "coercive diplomacy” effectively requires one side to capitulate with a major loss of face, it risks failure as many overly confident hawks have discovered..$^{30}$ To emphasize commitment to a mutually valuable next deal, the Obama administration should balance its dealings with Congress over contingent enhanced sanctions with a strong request for contingent enhanced incentives of the kind discussed in "prong one" of this recommended strategy. The focus of prong one is not about capitulation, face loss, and humiliation. Rather its substance and style focus on realizing significant, salient mutual gains. These would come about if and when Iran finally validates and provides verification of the genuinely peaceful nature of their nuclear program - to the satisfaction of the international community. Of course, the regime has steadfastly and publicly affirmed this to be the case along with its purported (religious) opposition to ever obtaining nuclear weapons. 
If negotiators can keep the focus on credible mutual gain from the next deal (prong one), albeit with credible negative consequences in the event of failure (prong two), the chances of success rise. After all, bargaining "in the shadow of the law" often produces results where bargaining without significant consequences of failure can promote endless stalling and inconclusive results. Facing the prospect of a strike or hostile takeover can catalyze the negotiations toward agreement. In the Iran case, a realistic deadline for a sensible, mutually beneficial deal in the shadow of conditionally enhanced sanctions would serve as a much milder "warning” version of Richard Holbrooke’s “bomb and talk” approach to Slobodan Milosovic leading to the Dayton accords that ended the Bosnian war.

Why Not Maximum Pressure for a Maximum Deal? Why adopt this two-prong strategy with both value-enhancing and contingent cost-imposing elements aimed at reaching a narrow nuclear deal? Why not go for a broader agreement? And why not keep up the pressure of sanctions? In short, why not maximum pressure for a maximum deal (like President Reagan used, arguably as a key to success, when dealing with the Soviets in the 1980s INF talks? $)^{31}$

There is considerable evidence that sanctions have imposed a heavy economic burden on Iran and have served as powerful prods for serious negotiation. Their actual effects, whether they are "crippling," and whether they will force Iran's leadership to accede to maximalist demands, are far less clear. ${ }^{32}$ In general, economic sanctions have a mixed record of success-including even harsh, sustained ones against Cuba and North Korea-especially where the elite can avoid their effects and the sanctioning coalition springs leaks. ${ }^{33}$ This should caution against overplaying our hand in Iran when there may be a real opening.

It is simply unclear whether continued full sanctions would induce Iranian capitulation. Given the reasonable chance that they are not, continuing to impose sanctions risks persuading Iranian skeptics that their hardliners' narrative is correct (that the U.S. and its allies are only interested in threats, sanctions, and pressure). As such, the interim nuclear opening may close before it can be meaningfully tested and before Iranian support can be built for greater benefits of an acceptable next deal. In this case, continued sanctions would represent a big, uncovered bet on the power of continuing sanctions that would have led to a dangerous slippery slope. This would be a bad move.

Now suppose that sanctions are strong enough to eventually induce Iranian capitulation. With a credible mechanism in place to impose even stronger ones in the event that negotiations fail (prong two of the recommended strategy), it would be possible to test Iranian intentions, make the benefits of the next deal more salient and persuasive to skeptics, but in the shadow or a much worse no-deal option.

In short, given the real possibility that sanctions won't force capitulation, deferring their imposition offers a useful hedge (if they won't) and a more powerful incentive (if they will).

A similar logic applies to the related question of whether to walk away from a narrower nuclear next deal if broader agreement can't be reached that contains other highly desirable provisions (e.g., for Iran to dismantle its entire nuclear infrastructure; to drop support for Assad, Hezbollah, and Hamas; to confess all past terror-related sins; to improve its human rights record; etc.). 
Start with the observation that preventing a nuclear-capable or nuclear-armed Iran is singularly important, has been a vital focus of American foreign policy, and affects most other Iran-related issues. By many accounts, even doing a narrow nuclear deal is an iffy proposition given the power of Iranian skeptics and hardliners, the importance the regime has evidently attached to nuclear capability, and the prospect of Iran obtaining that capability. ${ }^{34}$ To insist on wider provisions on yet other issues of importance to various constituencies risks overburdening the deal and energizing a larger set of skeptics. This could imperil a supportive coalition behind an acceptable nuclear deal, risking an extremely important, if narrower, accord. ${ }^{35}$ While other key interests in the Iran file will be the focus of ongoing efforts for years to come, one should not let hopes for a comprehensive dream deal scupper a good nuclear one. The United States and its allies will find it far more effective to address these Iranian issues if Iran has no nukes.

And of course, if the narrower deal can be reached that denies Iran an exercisable nuclear option, future diplomacy should certainly seek to build on it to encompass other issues. From another context, the counsel of former Secretary of State James Baker again seems apt: “you need to crawl before you walk and walk before you run.”36

Scarcely more than fifty years ago, President Kennedy faced what many of his advisors saw as an inescapable choice between two terrible options: acquiescing in Soviet nuclear weapons on Cuba, ninety miles from U.S. shores, or attacking Cuba at the very real risk of triggering a nuclear exchange that would snuff out tens of millions of American, Cuban, and Soviet lives. Yet, as Graham Allison detailed in teasing out possible parallels to the Iranian nuclear talks, Kennedy crafted an ingenious way out. ${ }^{37}$ After an American blockade bought vital time, Kennedy offered Khrushchev 1) a public pledge not to invade Cuba if missiles were removed (Khrushchev could tell his hardliners that “we safeguarded our ally’s revolution”), 2) tacit willingness to remove (obsolete) missiles from a U.S. base in Turkey within six months (Khrushchev could say "we won comparable concessions to removing Soviet missiles"), but 3) a private threat to attack within 24 hours if Soviet missiles weren't removed (a worsened no-deal option without public loss of face). “Acquiesce or attack” proved a false choice. The huge benefit was Soviet missiles out of Cuba; the costs included leaving a Communist puppet regime in Cuba and strained relations with Turkey, a U.S. ally.

Can a similar approach be crafted for the Iranian nuclear challenge? The interim deal temporarily freezes or rolls back key elements of Iran's nuclear program while buying valuable time to address the real complexities of a more comprehensive deal and permit advocates on each side to enlist the support of persuadable skeptics. Yet, without a credible deadline and high costs to impasse, that interim deal risks becoming a dangerous stopping point or slippery slope. To give it the best chance to serve as a stepping stone to a larger agreement, deal advocates should do their utmost to ensure that both sides adhere to the letter and spirit of the interim accord. And for any chance of acceptability, the terms of the next deal must meet the essential needs of each party.

Beyond these necessary conditions, negotiators should adopt a two-prong approach: crafting the most valuable possible nuclear deal while credibly worsening the consequences of no-deal. This will equip Iranian advocates to make a persuasive internal "victory speech" about why it is smarter and more valuable to say "yes" rather than knuckling under to, or defying, the 
reality of outside pressure. Even substantively modest but publicly salient incentives may be helpful ingredients in crafting that "speech" to strengthen and enlarge the pro-deal constituency in Iran. At the same time, if their P5+1 counterparts can make an equivalent appeal to their own skeptics, a sufficient winning coalition on behalf of a fuller deal just may emerge that will be strong enough to overcome the blockers.

\footnotetext{
${ }^{1}$ Professor, Harvard Business School and Director, Harvard Negotiation Project. Contact: jsebenius@hbs.edu. Thanks to Nancy Buck, Matt Bunn, Paul Levy, Deepak Malhotra, Michael Singh, and Will Tobey for insightful suggestions.

${ }^{2}$ The terms of the interim agreement are discussed at http://iranmatters.belfercenter.org/negotiations.

${ }^{3}$ For a skeptical case about whether a zone of possible agreement even existed during many phases of the prior negotiations, see Sebenius, James K., and Michael K. Singh. "Is a Nuclear Deal with Iran Possible? An Analytical Framework for the Iran Nuclear Negotiations." International Security 37, no. 3 (Winter 2012): 52-91. Much of the present analysis directly draws on this joint article but without implicating Singh, whose views may differ from mine.

${ }^{4}$ For example, see Charles Krauthammer, “Sucker’s Deal,” at http://www.washingtonpost.com/opinions/charles-krauthammersuckers-deal/2013/11/21/9d03e966-52dc-11e3-a7f0-b790929232e1_story.html

${ }^{5}$ Mitchell B. Reiss and Ray Takeyh, "Don’t Get Suckered by Iran: Fix the Problems With the Interim Accord,” Council on Foreign Relations, January 2, 2014, at http://www.foreignaffairs.com/articles/140620/mitchell-b-reiss-and-ray-takeyh/dont-getsuckered-by-iran.

${ }^{6}$ David Ignatius, “Iran’s Hardliners Resist Nuclear Deal,” Washington Post, December 17, 2013, at http://www.washingtonpost.com/opinions/david-ignatius-irans-hard-liners-resist-nuclear-deal/2013/12/17/b7927d04-6742-11e38b5b-a77187b716a3_story.html

${ }^{7}$ Beeman, William O. The “Great Satan” vs. the "Mad Mullahs:” How the United States and Iran Demonize Each Other. Westport: Praeger, 2005

${ }^{8}$ I sidestep the knotty legal and political problems of relaxing sanctions for U.S. negotiators. But see Rachel Cohen, "President Obama Can Ease Sanctions on Iran by Himself - But That’s Not the End of the Story.” Washington Monthly, October 21, 2013.

${ }^{9}$ Mark Dubowitz, "Early Signs of an Iranian Economic Recovery, in FDD Iran Sanctions Analysis, January 9, 2014, at http://www.defenddemocracy.org/media-hit/early-signs-of-an-iranian-economic-recovery/.

${ }^{10}$ Security and territorial integrity guarantees offer one example, as do a wide range of potential trade and investment possibilities. In the nuclear realm, for example, both sides interests could be served by preferential, even subsidized, fuel banking possibilities or other legally binding sources of nuclear fuel for Iranian civilian reactors; see, e.g., "Time for a More Creative Negotiating Strategy with Iran,” Center for Strategic and International Studies, http://csis.org/blog/time-more-creativenegotiating-strategy-iran, accessed November 7, 2013.

${ }^{11}$ See Benjamin Weinthal, “Germany, Inc. Heads to Teheran,” ForeignPolicy.com, January 31, 2014, http://www.foreignpolicy.com/articles/2014/01/31/german_corporations_do_business_with_iran. See also Najmeh Bozorgmehr and Hugh Carnegy, "French Businesses Head for Teheran,” Financial Times, February 3, 2014, p. 1.

${ }^{12}$ See http://www.treasury.gov/resource-center/sanctions/Programs/Documents/iran_glg.pdf.

${ }^{13}$ See http://www.reuters.com/article/2014/02/11/us-usa-iran-idUSBREA1A2B920140211.

${ }^{14}$ For example, for the extensive 2008 incentives package offered by the $\mathrm{P} 5+1$ that went nowhere in the talks, see http://iipdigital.usembassy.gov/st/english/texttrans/2008/06/20080617165530eaifas0.1855738.html\#axzz2j33M9BrN.

${ }^{15}$ See the remarks of Gary Samore at http://www.bloombergview.com/articles/2014-02-18/obama-weapons-expert-no-chance-ofsuccess-with-iran.

${ }^{16}$ For a discussion of the Turkish activities, see Nader Habibi’s “The Iranian Connection in Turdey’s Corruption Scandal,” at http://iranmatters.belfercenter.org/blog/iranian-connection-turkey\%E2\%80\%99s-corruption-scandal. On the Russian link, see Peter Foster, “White House Concerned About Russia’s Oil for Goods Deal with Iran,” The Telegraph, January 14, 2014 at http://www.telegraph.co.uk/news/worldnews/northamerica/usa/10570147/White-House-concerned-about-Russias-oil-for-goodsdeal-with-Iran.html - disqus_thread.

${ }^{17}$ Paul Richter and Ramin Mostaghim, “Iran nuclear deal debate: How much does Tehran benefit?” in the Los Angeles Times, January 20, 2014, at http://www.latimes.com/world/worldnow/la-fg-wn-iran-nuclear-deal-debate20140120,0,2063763.story\#axzz2rSzIipxx.

${ }^{18}$ See, for example, David E. Sanger and Eric Schmitt, “To Calm Israelis, U.S. Offers Ways to Re- strain Iran,” New York Times, September 3, 2012; or Allison, Graham. "Will Iran Get a Bomb—Or Be Bombed Itself_-This Year?" The Atlantic, August 1, 2013, available online at http://www.theatlantic.com/international/archive/2013/08/will-iran-get-a-bomb-or-be-bombed-thisyear/278253/.

${ }^{19}$ For examples of more stringent sanctions possibilities, see Kenneth Katzman’s “Iran Sanctions” (Washington: Congressional Research Service), October 11, 2013 (Report RS20871), pp. 63-64.

20 The right criteria are discussed below for such a bill, which the Obama administration opposes; see Gary Samore,

“Anticipating Objections to the Nuclear Weapon Free Act” at http://iranmatters.belfercenter.org/blog/obama-administrationsobjections-nuclear-weapon-free-iran-act. A more detailed analysis of the deal-killing provisions of this bill can be found in
} 
Edward Levine’s “Analysis of Faults in the Menendez-Kirk Iran Sanctions Bill (S. 1881),” accessible at

http://armscontrolcenter.org/issues/iran/articles/analysis_of_faults_in_the_menendez-kirk_iran_sanctions_bill_s_1881/.

${ }^{21}$ Although, technically, the kind of contingent sanctions advocated here would not constitute new sanctions to go into effect during the interim negotiations.

${ }^{22}$ See the letter signed by a number of foreign policy luminaries at http://www.scribd.com/doc/196538945/Press-Release-andLetter-Jan-6-2013. See also two strong critiques of contingent sanctions, especially as part of the Menendez-Kirk bill: Colin H.

Kahl "The Danger of New Iran Sanctions," http://nationalinterest.org/commentary/the-danger-new-iran-sanctions-9651 and Reza Marashi and Trita Parsi, “The wrong path to peace with Iran,” http://edition.cnn.com/2013/12/31/opinion/marashi-parsi-iranpeace/index.html?sr=sharebar_twitter\#cnn-disqus-area.

${ }^{23}$ Robert Menendez, “A Diplomatic Insurance Policy Against Iran,” Washington Post, January 9, 2014 in http://www.washingtonpost.com/opinions/a-diplomatic-insurance-policy-against-iran/2014/01/09/f50ec8dc-77b8-11e3-af7f13bf0e9965f6_story.html.

${ }^{24}$ See the letter signed by a number of foreign policy luminaries at http://www.scribd.com/doc/196538945/Press-Release-andLetter-Jan-6-2013.

${ }^{25}$ Barack Obama, White House Press Conference, December 20, 2013 accessed at http://www.whitehouse.gov/the-pressoffice/2013/12/20/press-conference-president.

${ }^{26}$ John Kerry, Remarks at the Saban Forum, December 7, 2013 at http://www.state.gov/secretary/remarks/2013/12/218506.htm.

${ }^{27}$ For an excellent analysis of the minimum essential conditions for this, see Graham Allison, "In Iran, Perfect is the Enemy of the Good,” in ForeignPolicy.com, January 22, 2014 at http://www.foreignpolicy.com/articles/2014/01/22/us_iran_nuclear_deal.

${ }^{28}$ E.g. Reiss and Takeyh.

${ }^{29}$ See http://blogs.rollcall.com/wgdb/83-senators-send-iran-letter-to-obama/ and http://www.google.com/hostednews/afp/article/ALeqM5hxfE6ilf9vRjTXeQDk_JOwaD5xJg?docId=d2b99583-48ee-4d4a-b23eb23c58a7f925, respectively.

${ }^{30}$ See Robert J. Art, Patrick M. Cronin, The United States and Coercive Diplomacy, Washington: US Institute of Peace Press, 2003, or Robert A. Pape, “Why Economic Sanctions Do Not Work,” International Security, vol. 22, No. 2, (Autumn, 1997), 90136.

${ }^{31}$ See George P. Shultz, “The Gipper’s Guide to Negotiating,” at

http://online.wsj.com/news/articles/SB10001424052702303531204579204204025788642?mod=WSJ_hps_sections_opinion.

32 A fairly sophisticated take in the interaction between the sanctions and Iranian politics can be found in Colin H. Kahl "The

Danger of New Iran Sanctions,” http://nationalinterest.org/commentary/the-danger-new-iran-sanctions-9651. Kenneth Katzman’s "Iran Sanctions” (Washington: Congressional Research Service), October 11, 2013 (Report RS20871) provides a fuller review of the sanctions' effects, which are contested. See Djavad Salehi-Isfahani, "An exchange on the economic costs of Iran's nuclear program," December 23, 2013. http://iranmatters.belfercenter.org/blog/macroeconomic-costs-iran\%E2\%80\%99s-nuclearprogram-\%E2\%80\%93-two-corrections.

33 See, e.g., Art and Pape.

${ }^{34}$ See, e.g., Sebenius and Singh, pp. 59-60.

${ }^{35}$ Colin H. Kahl, “Inflection Point: Requirements for an Enduring Diplomatic Solution to the Iranian Nuclear Challenge,” in Policy Brief, Center for a New American Security, November 2013, at

http://www.cnas.org/files/documents/publications/CNAS_InflectionPoint_Kahl_0.pdf.

${ }^{36}$ Cited with respect to the Madrid Conference in Aaron D. Miller, The Much Too Promised Land, New York, Bantam, 2008, p. 217.

${ }^{37}$ Graham Allison, “What Would JFK Have Done About Iran?” at http://globalpublicsquare.blogs.cnn.com/2013/11/22/whatwould-jfk-have-done-about-iran/. 